\title{
Peran Moderasi Kepemilikan Institusional Terhadap Determinan Return On Equity Di Bursa Efek Indonesia
}

\author{
Surya Sanjaya ${ }^{1 *}$, Jufrizen $^{2)}$ \\ Fakultas Ekonomi dan Bisnis Universitas Muhammadiyah Sumatera Utara \\ *Email: jaya_leo07@yahoo.com
}

\begin{abstract}
\begin{tabular}{c}
\hline Article Info \\
\hline Received: \\
28 Agustus 2017 \\
Revised: \\
12 September 2017 \\
Accepted: \\
10 Oktober 2017 \\
\hline
\end{tabular}
ABSTRAK

Penelitian ini bertujuan untuk menganalisis pengaruh Perputaran Kas, Perputaran Piutang dan Perputaran Aktiva Tetap terhadap Return On Equity (ROE) dengan Kepemilikan Institusi sebagai variabel moderating baik secara parsial maupun simultan. Pendekatan penelitian ini adalah pendekatan kuantitatif, populasi dalam penelitian ini adalah perusahaan Properti dan Real Estate yang terdaftar di Bursa Efek Indonesia tahun 2011-2015, teknik pengambilan sampel dengan cara purposive sampling dari 50 perusahaan, dan 14 perusahaan yang memenuhi kriteria menjadi sampel, jenis data dalam penelitian ini adalah data sekunder. Teknik Analisis menggunakan analisis regresi linear berganda. Hasil penelitian ini menunjukan bahwa secara parsial Perputaran Kas berpengaruh dan perputaran piutang secara parsial terhadap Return On Equity dan kepemilikan Institusi tidak memoderasi pengaruh keduanya. Perputaran Aktiva Tetap berpengaruh signifikan terhadap Return On Equity dan kepemilikan Institusi memoderasi. Secara simultan variabel Perputaran Kas, Perputaran Piutang dan Perputaran Aktiva Tetap berpengaruh signifikan terhadap Return On Equity. Kepemilikan Institusi berpengaruh tidak signifikan terhadap Return On Equity dan Kepemilikan Institusi memoderasi hubungan antara Perputaran Kas, Perputaran Piutang dan Perputaran Aktiva Tetap dengan Return on Equity. Kepemilikan Institusi sebagai Variabel Moderating dalam penelitian ini.
\end{abstract}

Kata Kunci: Perputaran Kas, Perputaran Piutang, Perputaran Aktiva Tetap, Return On Equity, Kepemilikan Institusi

\section{The role of moderation of institutional ownership on return on equity determinant in Indonesia Stock Exchange (IDX)}

\begin{abstract}
This study aims to analyze the effect of Cash Turnover, Turnover Turnover and Fixed Assets Turnover to Return On Equity (ROE) with Institutional Ownership as a moderating variable either partially or simultaneously. The approach of this research is quantitative approach, population in this research are property and real estate company listed in Indonesia Stock Exchange year 2011-2015, sampling technique by purposive sampling from 50 companies, and 14 companies that fulfill criteria become sample, data type in this research is secondary data. Analysis technique using multiple linear regression analysis. The results of this study show that partially Cash Turnover influential and partial receivables turnover on Return On Equity and ownership of the Institution does not moderate the influence of both. Fixed Assets Turn over significant effect on Return On Equity and moderate Institutional ownership. Simultaneously variable Cash Turnover, Receivable Turnover and Fixed Assets Turnover significant effect on Return On Equity. Institutional Ownership has no significant effect on Return On Equity and Institutional Owners moderate the relationship between Cash Turnover, Accounts Receivable Turnover and Fixed Assets Turnover with Return on Equity. Ownership of Institutions as Moderating Variables in this study.
\end{abstract}

Keywords: Accounts Receivable Turnover, Cash Turnover, , Fixed Assets Turnover, Institutional Ownership, Return On Equity

How to cite:

Sanjaya, S., dan Jufrizen. (2017). Peran Moderasi Kepemilikan Institusional Terhadap Determinan Return On Equity Di Bursa Efek Indonesia. Jurnal Ilmiah Manajemen \& Bisnis, 18(2), 189-205. 


\section{PENDAHULUAN}

Kelangsungan hidup perusahaan (going concern) dipengaruhi oleh banyak hal antara lain profitabilitas perusahaan itu sendiri (Brigham dan Houston, 2011). Untuk mengukur tingkat keuntungan suatu perusahaan, digunakan rasio keuntungan perofitabilitas yang dikenal juga dengan nama rasio rentabilitas. Mengukur kemampuan perusahaan dalam menjalankan aktivitasnya untuk menghasilkan laba atau profit cara yang dapat digunakan adalah salah satunya dengan menggunakan rasio Profitabilitas (Kasmir, 2012).

Pentingnya profitabilitas dapat dilihat dengan mempertimbangkan dampak yang berasal dari ketidak mampuan perusahaan mendapatkan laba yang maksimal untuk mendukung kegiatan operasionalnya. Cara memperhitungkan profitabilitas adalah bermacam- macam dan tergantung pada laba dan aktiva atau modal yang akan diperbandingkan satu dengan yang lainnya. Salah satu cara untuk menghitung profitabilitas adalah Return On Equity (ROE) (Fajri, 2013). Syamsuddin (2009) menyatakan bahwa ROE merupakan suatu pengukuran dari penghasilan (income) yang tersedia bagi para pemilik perusahaan (baik pemegang saham biasa maupun pemegang saham preferen) atas modal yang mereka investasikan di dalam perusahaan". Maka dapat disimpulkan bahwa Return on Equity adalah kemampuan perusahaan dalam menghasilkan laba yang diukur dengan membandingkan antara laba bersih dengan ekuitas biasa (total ekuitas). Laba merupakan dasar ukuran kinerja bagi kemampuan manajemen dalam mengoperasikan harta perusahaan (Prawironegoro dan Purwanti, 2008). Laba harus direncanakan dengan baik agar manajemen dapat mencapainya secara efektif. Ekuitas adalah hak residu (nilai sisa) aktiva perusahaan dikurangi kewajiban. Pengungkapan informasi ekuitas pemegang saham akan sangat dipengaruhi oleh tujuan penyajian informasi tersebut kepada pemakai statemen keuangan.

Pendapatan adalah jumlah harta kekayaan awal periode ditambah keseluruhan hasil yang diperoleh selama satu periode, yaitu pendapatan dari penjualan barang dan jasa. Martani, (2012) menyatakan bahwa pendapatan merupakan penghasilan yang berasal dari aktivitas operasi utama perusahaan.

Setiap perusahaan dalam menjalankan usahanya selalu membutuhkan Kas (Riyanto, 2010). Kas diperlukan baik untuk membiayai operasi perusahaan sehari-hari maupun untuk mengadakan investasi baru dalam aktiva tetap, sehingga kas harus dikelola dengan tepat, yang salah satunya dengan memperhatikan tingkat perputaran kasnya. Tingkat perputaran kas yang tinggi menunjukkan efisiensi dalam penggunaan kas, sehingga perusahaan bisa memaksimalkan laba. Dan sebaliknya, tingkat perputaran kas yang rendah menyebabkan perusahaan kurang bisa memaksimalkan laba.

Penelitian ini menggunakan kepemilikan institusional karena kepemilikan institusional mempunyai arti penting dalam memonitor manajemen dalam mengelola perusahaan. Kepemilikan institusional dalam proporsi besar mempunyai peranan dalam monitoring perusahaan sehingga mampu memberikan tekanan agar pelaksanaan good corporate governance berjalan.

Berdasarkan latar belakang, maka peneliti merumuskan permasalahan sebagai berikut apakah ada pengaruh Perputaran Kas, Perputaran Piutang dan Perputaran Aktiva Tetap secara parsial dan simultan terhadap Return on Equity pada perusahaan Properti dan Real Estate yang terdaftar di Bursa Efek Indonesia? Bagimana Kepemilikan institusional memoderasi pengaruh Perputaran Kas, Perputaran Piutang, Perputaran Aktiva Tetap terhadap Return on Equity pada perusahaan Properti 
dan Real Estate yang terdaftar di Bursa Efek Indonesia?

\section{KAJIAN TEORI \\ Return on Equity}

Return on Equity (ROE) merupakan bagian dari rasio profitabilitas dalam menganalisa laporan keuangan atas laporan kinerja keuangan perusahaan. Brigham dan Houston (2011) menyatakan bahwa Return on Equity/ Pengembalian atas ekuitas biasa yaitu rasio laba bersih terhadap ekuitas biasa atau mengukur tingkat pengembalian atas investasi pemegang saham biasa. Hani (2014) menyatakan bahwa Return on Equity (ROE) menunjukan kemampuan dari ekuitas (umumnya saham biasa) yang dimiliki perusahaan untuk menghasilkan laba. Selanjutnya Sudana (2011) menyatakan bahwa Return on Equity (ROE) adalah rasio yang menunjukan kemampuan perusahaan untuk menghasilkan laba setelah pajak dengan menggunakan modal sendiri yang dimiliki perusahaan. Lebih lanjut Ross et.al (2009) menyatakan bahwa Return On Equity (ROE) adalah ukuran atau dari hasil yang diperoleh para pemegang saham sepanjang tahun. Berdasarkan pengertian diatas dapat disimpulkan bahwa Return on Equity adalah kemampuan perusahaan dalam menghasilkan laba yang diukur dari jumlah investasi para pemegang saham. ROE menunjukan keefisiensinan perusahaan dalam mengelola seluruh ekuitasnya untuk memperoleh pendapatan. Ross et.al (2009) menyatakan bahwa faktor yang mempengaruhi Return On Equity dalam kemampuan sebuah perusahaan untuk mempertahankan pertumbuhan akan secara eksplisit tergantung pada empat faktor yaitu 1) margin laba, 2) kebijakan deviden, 3) kebijakan keuangan, dan 4) perputaran total aset.

\section{Perputaran Kas}

Perputaran

kemampuan kas kas

dalam menghasilkan pendapatan sehingga dapat dilihat berapa kali uang kas berputar dalam satu periode tertentu. Perputaran kas adalah perputaran sejumlah modal kerja yang tertanam dalam kas dan bank dalam satu periode akuntansi. Perputaran kas diketahui dengan membandingkan antara jumlah pendapatan dan pemberian pinjaman dengan kas ratarata. Dengan demikian tingkat perputaran kas menunjukan kecepatan kembalinya modal kerja yang tertanam pada kas atau setara kas menjadi kas kembali melalui penjualan atau pendapatan. Perputaran kas manunjukkan pada berapa kali uang kas yang berputar dalam satu periode. Riyanto (2010) menyatakan pendapatnya tentang perputaran kas, mengatakan bahwa perputaran kas adalah perbandingan antara penjualan dengan jumlah kas rata-rata. Dari tingkat perputaran inilah merupakan ukuran dalam efisiensi penggunaan kas yang dilakukan oleh perusahaan karena tingkat perputaran kas tersebut memberi gambaran kecepatan arus kas dan kembalinya kas yang telah ditanamkan didalam modal kerja pada periode tersebut. Sedangkan Kasmir (2012) menjelaskan bahwa Perputaran kas (cash turnover) berfungsi untuk mengukur tingkat kecukupan modal kerja perusahaan yang dibutuhkan untuk membayar tagihan dan membiayai penjualan. Artinya rasio ini digunakan untuk mengukur tingkat ketersediaan kas untuk membayar tagihan (utang) dan biaya-biaya yang berkaitan dengan penjualan. Sedangkan Riyanto (2010) menyatakan perputaran kas adalah untuk mengetahui efesiensi atau tidaknya pengguna kas dalam perusahaan. Perbandingan antara penjualan dengan jumlah kas rata-rata menggambarkan tingkat perputaran kas. Semakin tinggi perputaran kasnya akan semakin baik kondisi perusahaan. Sebaliknya jika perputaran kas perusahaan sering mengalami penyimpangan maka perusahaan harus berusaha untuk selalu menjaga persediaan kas minimal. 


\section{Perputaran Piutang}

Menurut Jumingan (2009) terkait piutang bahwa piutang timbul karena adanya penjualan barang atau jasa secara kredit. Hasil perputaran piutang yang semakin tinggi adalah semakin baik, karena modal kerja yang ditanamkan dalam bentuk piutang akan semakin rendah. Perputaran piutang adalah perputaran piutang merupakan periode terikatnya modal dalam piutang yang terantung pada syarat pembayaran, makin lunak atau makin lama syarat pembayarannya, berarti bahwa tingkat pembayarannya selama priode tertentu adalah semakin rendah. (Riyanto, 2010). Syamsuddin (2009) menyatakan bahwa perputaran piutang adalah untuk mengukur likuiditas atau aktivitas dari piutang perusahaan. Perputaran piutang merupakan rasio yang digunakan untuk mengukur berapa lama penagihan piutang selama satu periode atau berapa kali dana yang ditanam dalam piutang ini berputar dalam satu periode. Semakin tinggi rasio menunjukan bahwa modal kerja yang ditanamkan dalam piutang semakin rendah (bandingkan dengan rasio tahun sebelumnya) dan tentunya kondisi ini bagi perusahaan semakin baik. Sebaliknya jika rasio semakin rendah ada over invesment dalam piutang. Hal yang jelas rasio perputaran piutang memberikan pemahaman tentang kualitas piutang dan kesuksesan penagihan piutang. Dari penjelasan diatas dapat disimpulkan bahwa perputaran piutang adalah rasio yang menunjukkan seberapa besar suatu perusahaan dapat menagih piutangnya dalam suatu periode. Dan semangkin tinggi tingkat perputaran piutang tersebut maka semangkin baik perusahaan tersebut .

\section{Perputaran Aktiva Tetap}

Munawir (2010) menyatakan bahwa perputaran aktiva tetap (fixed asset turnover) yaitu rasio antara penjualan neto dengan aktiva tetap. Pada dasarnya setiap perusahaan, aktiva tetap memiliki makna dari arti yang sama, meskipun banyak cara orang mengungkapkan aktiva tetap dengan istilah yang berbeda-beda, perbedaan tersebut disesuaikan dengan cara memandang aktiva itu oleh badan organisasi atau perusahaan yang menggunakannya. Rasio perputaran aktiva tetap digunakan oleh manajemen perusahaan untuk mengukur efisiensi penggunaan aktiva tetap, Brigham dan Houston (2011) menyatakan bahwa fixed asset turnover merupakan suatu rasio yang mengukur seberapa efektifitaskah perusahaan menggunakan pabrik atau peralatannya. Dan merupakan rasio dari penjualan terhadap aktiva tetap bersih. Berdasarkan definisi diatas dapat disimpulkan bahwa perputaran aktiva tetap adalah perbandingan antara penjualan dengan aktiva tetap netto pada suatu perusahaan. Rasio perputaran aktiva tetap menunjukan bagaimana perusahaan menggunakan aktiva tetapnya seperti gedung, kendaraan, mesin-mesin, perlengkapan kantor dalam menunjang penjualan perusahaan.

\section{Kepemilikan institusional}

Kepemilikan Institusional adalah kepemilikan saham oleh pemerintah, institusi keuangan, institusi berbadan hukum, institusi luar negeri, dana perwalian dan institusi lainnya pada akhir tahun (Shien, et. al 2006). Widarjo (2010) menyatakan kepemilikan institusional merupakan kondisi dimana institusi memiliki saham dalam suatu perusahaan. Institusi tersebut dapat berupa institusi pemerintah, institusi swasta, domestik maupun asing. Marselina, et al., (2013) menyimpulkan bahwa kepemilikan institusional merupakan kepemilikan saham oleh lembaga dari eksternal. Investor institusional tidak jarang menjadi mayoritas dalam kepemilikan saham. Hal tersebut dikarenakan para investor institusional memiliki sumber daya yang lebih besar 
daripada pemegang saham lainnya sehingga dianggap mampu melaksanakan mekanisme pengawasan yang baik. Dari berbagai pengertian di atas dapat disimpulkan bahwa kepemilikan institusional merupakan kondisi di mana institusi atau lembaga eksternal yang turut memiliki saham di dalam perusahaan.

\section{Kerangka Konsep dan Pengembangan Hipotesis}

Kepemilikan institusional adalah kepemilikan saham oleh pihak eksternal (Marselina, et al., 2013), dan semakin tinggi kepemilikan institusional maka semakin besar kontrol dan pengawasan terhadap perusahaan. Banyaknya saham yang ditanam oleh perusahaan akan meningkatkan keyakinan perusahaan bahwa banyak investor yang percaya akan kemampuan perusahaan dalam memberikan keuntungan bagi para pemegang saham, sehingga perusahaan akan terus meningkatkan keuntungan dari setiap aktivitas perusahaan. Hal ini membuktikan dengan adanya kepemilikan institusional akan meningkatkan return on equity perusahaan melalui perputaran kas yang dimiliki perusahaan, karena saham yang ditanamkan dapat menjadi modal perusahaan dalam menjalankan aktivitasnya. Salah satu upaya yang dilakukan oleh suatu perusahaan dalam mencapai nilai keunggulan bersaing yaitu dengan melakukan penjualan secara kredit, namun menimbulkan piutang bagi perusahaan. Keyakinan oleh perusahaan dalam memberikan kredit kepada pembeli (konsumen) atas barang atau jasa, umumnya dilakukan untuk memperbesar penjualan dan meningkatkan laba. Piutang yang dimiliki suatu perusahaan mempunyai hubungan yang erat dengan volume penjualan kredit. Perputaran piutang yang tinggi menunjukan semakin efisien dan efektif perusahaan dalam mengelola piutang sebagai sumber pemasukan dan pendapatan perusahaan sehingga akan meningktakan profitabilitas perusahaan. Keadaan perputaran piutang yang semakin tinggi menunjukan keberhasilan perusahaan dalam melakukan strategi penjualan. Sehingga semakin tinggi tingkat perputaran piutang suatu perusahaan maka semakin tinggi pula Return on Equity ROE yang dihasilkan perusahaan.

Adanya kepemilikan institusional menjadikan perusahaan lebih mengoptimalkan kinerja perusahaan, dan dalam pembahasan ini kepemilikan institusional memoderasi hubungan perputaran piutang terhadap Return On Equity, artinya kepemilikan institusional yang ada dalam perusahaan dapat menjadi pengawas serta pendanaan bagi kegiatan perusahaan, dana yang ditanamkan dalam perusahaan berupa saham akan membuat perusahaan lebih giat untuk mendapatkan keuntungan yang lebih banyak sehingga dapat menjaga perputaran piutang dan menghasilkan Return on Equity yang meningkat. Perputaran asset tetap adalah rasio yang digunakan untuk mengukur apakah perusahaan sudah menggunakan kapasitas aset tetap sepenuhnya secara efektif dan efisien. Tingkat pemanfaatan aset tetap penting karena investasi dalam operasional usaha dan peralatan jumlahnya besar dan berjangka waktu lama. Semakin besar perputaran aktiva tetap maka akan semakin baik, karena setiap putaran menghasilkan manfaat berupa keuntungan. Brigham dan Houston (2011) menyatakan bahwa Fixed Asset Turnover (FATO) adalah mengukur seberapa efektif perusahaan menggunakan pabrik dan peralatannya. Pengelolaan aktiva tetap yang tidak tepat dapat menimbulkan kerugian dan kehilangan kesempatan yang begitu besar karena tidak dapat mengoptimalkan kinerja dan manfaat dari aktiva tersebut. Sebaliknya pengelolaan aktiva tetap yang dilakukan dengan tepat akan memberikan keuntungan begitu besar karena dapat mengoptimalkan kinerja dan manfaat aktiva tersebut. 
Dengan demikian semakin tinggi tingkat rasio perputaran aktiva tetap menunjukan kemampuan perusahaan dalam mengelola aktiva tetapnya untuk menghasilkan keuntungan, namun sebaliknya jika tingkat rasio perputaran aktiva tetap rendah maka perusahaan tidak mampu mengoperasionalkn aktiva sebagai modal mengahsilkan laba. Hal ini menunjukan bahwa tingkat perputaran aktiva tetap yang tinggi akan meningkatkan perofitabilitas terutama Return on Equity (ROE) perusahaan.

Kepemilikan institusional berperan sebagai pengawas dan pendanaan bagi perusahaan sehingga perusahaan dapat menjalankan kegiatannya dengan baik, membiayai segala keperluan perusahaan, sehingga menghasilkan laba yang diharapkan, kepemilikan institusional memoderasi hubungan perputaran aktiva tetap terhadap return on equity, karena dengan banyaknya atau tingginya kepemilikan institusional akan meningkatkan kepercayaan perusahaan dan perusahaan dapat mengoptimalkan harta kekayaan yang dimiliki perusahaan untuk lebih meningkatkan laba. Return on Equity (ROE) merupakan rasio untuk mengukur kemampuan perusahaan dalam mencari keuntungan dengan modal sendiri. Profit merupakan elemen terpenting agar kelanjutan dari perusahaan tetap terjamin. Brigham and Houston (2011) menyatakan Return On Equity (ROE) adalah pengembalian atas ekuitas biasa yaitu rasio laba bersih terhadap ekuitas biasa atau mengukur tingkat pengembalian atas investasi pemegang saham biasa. Semakin kecil (rendah) rasio ini, semakin kurang baik manajemen perusahaan dalam menggunakan ekuitasnya untuk menghasilkan laba. Demikian pula sebaliknya, semakin besar (tinggi) rasio ini, semakin baik manajemen perusahaan dalam menggunakan ekuitasnya dalam menghasilkan laba.
Hipotesis dari penelitian ini adalah sebagai berikut Ada pengaruh Perputaran Kas, Perputaran Piutang dan Perputaran Aktiva Tetap secara parsial dan simultan terhadap Return on Equity pada perusahaan Properti dan Real Estate yang terdaftar di Bursa Efek Indonesia, Kepemilikan institusional memoderasi pengaruh Perputaran Kas, Perputaran Piutang, Perputaran Aktiva Tetap terhadap Return on Equity pada perusahaan Properti dan Real Estate yang terdaftar di Bursa Efek Indonesia.

\section{METODE}

Pendekatan penelitian yang digunakan dalam penelitian ini adalah dengan menggunakan pendekatan asosiatif. Penelitian ini menggunakan data sekunder dan bersifat empiris, dimana data yang diperoleh dari dokumen dengan cara melakukan browsing pada situs resmi Bursa Efek Indonesia (BEI). Populasi dalam penelitian ini adalah semua perusahaan yang masuk dalam perhitungan indeks Properti dan Real Estate selama periode tahun 20102014 sebanyak 50 perusahaan. Pemilihan sampel penelitian ini ditentukan dengan menggunakan desain sampel nonprobabilitas dengan metode proposive sampling, dimana peneliti memilih sampel berdasarkan penilaian beberapa karakteristik anggota sampel yang disesuaikan dengan pertimbangan tertentu dan sampel yang diperoleh sebanyak 14 (empat belas) perusahaan Properti dan Real Estate. Teknik pengumpulan data yang digunakan dalam penelitian ini adalah dengan menggunakan teknik dokumentasi. Data yang digunakan dalam penelitian ini dikumpulkan dengan mendokumentasi dari laporan keuangan perusahaan Properti dan Real Estate. Sumber data yang digunakan dalam penelitian ini adalah sumber data sekunder yang diperoleh dengan mengambil data-data yang di publikasikan pada situs resmi Bursa Efek Indonesia (BEI). Teknik 
Analisis data menggunakan analisis regresi linear berganda dan pengujian hipotesis serta uji HRA dengan menggunakan SPSS versi 20.00 .

\section{HASIL PENELITIAN PEMBAHASAN Hasil Penelitian}

Metode yang digunakan untuk menguji hipotesis adalah regresi linear berganda. Hal ini sesuai dengan rumusan masalah, tujuan masalah, dan hipotesis penelitian ini. Analisis regresi linear berganda bertujuan untuk melihat seberapa besar koefisien regresi yang berpengaruh antara variabel bebas terhadap variabel terikat secara parsial (masing-masing). Berikut hasil pengolahan data dengan menggunakan SPSS versi 20.00.

Tabel 1. Hasil Pengujian Regresi Berganda Coefficients $^{\mathrm{a}}$

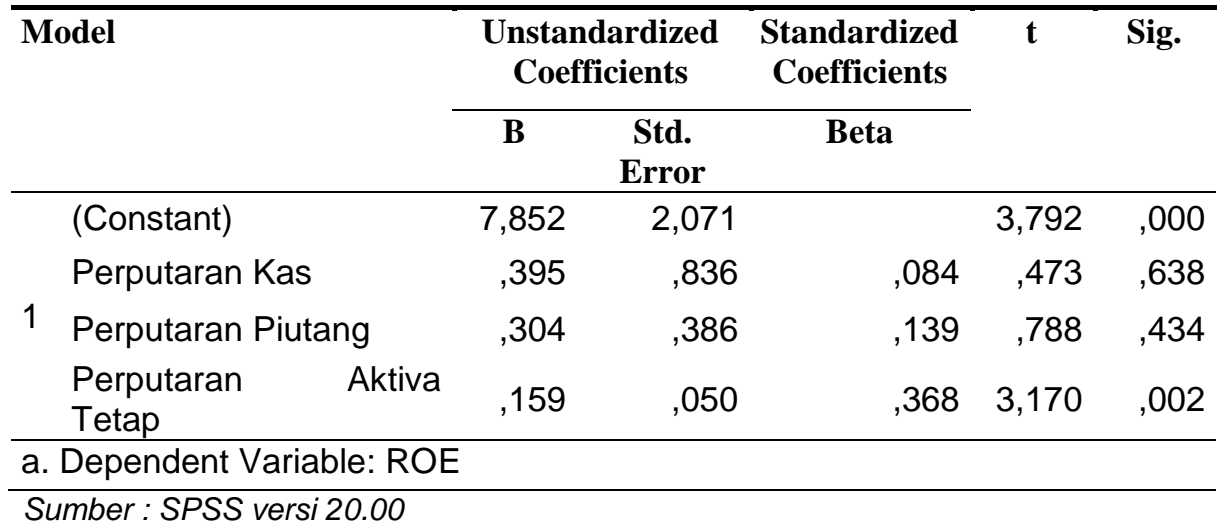

Pada tabel 1 dapat diformulasikan persamaan regresi linier berganda sebagai berikut: $Y=7,852+0,395 X_{1}+0,304 X_{2}+$ $0,159 \mathrm{X}_{3}$. Dari persamaan tersebut dapat diartikan nilai konstanta sebesar 7,852 dan apabila variabel bebas dalam keadaan tetap atau konstan maka ROE akan meningkat sebesar 785,2\% dan apabila Perputaran Kas $\left(\mathrm{X}_{1}\right)$ meningkat $1 \%$ sementara variabel bebas lainnya tetap maka akan meningkatkan ROE sebanyak 0,395, dan bila Perputaran Piutang $\left(\mathrm{X}_{2}\right)$ meningkat $1 \%$ sementara variabel bebas lainnya tetap maka akan meningkatkan ROE sebanyak 0,304 kemudian bila Perputaran Aktiva Tetap $\left(\mathrm{X}_{3}\right)$ meningkat $1 \%$ sementara variabel bebas lainnya tetap maka akan meningkatkan ROE sebanyak 0,159 .

Selanjutnya untuk menguji hipotesis dengan menggunakan persamaan analisis regresi hierarki dapat dicari dengan menggunakan program spss versi 20.00 dan menyederhanakan hasilnya sebagai berikut :

Tabel 2. Hubungan Perputaran Kas terhadap Return on Equity dimoderasi oleh

Kepemilikan Institusi

\begin{tabular}{clrrrr}
\hline $\begin{array}{c}\text { No. } \\
\text { Model }\end{array}$ & Variables & Coefficient & $\begin{array}{c}\text { Standard } \\
\text { Error }\end{array}$ & t-Value & Significant-t \\
\hline 1 & (Constant) & 11,879 & 1,739 & 6,832 & 0,000 \\
& Perp. Kas & 0,533 & 0,565 & 0,944 & 0,349 \\
& $R^{2}$ & 0,013 & & & \\
& $R^{2}$ change & 0,013 & & & \\
& Sig. F change & 0,349 & & & \\
2 & (Constant) & 15,510 & 4,382 & 3,540 & 0,001 \\
& Perp. Kas & 0,322 & 0,612 & 0,525 & 0,601
\end{tabular}




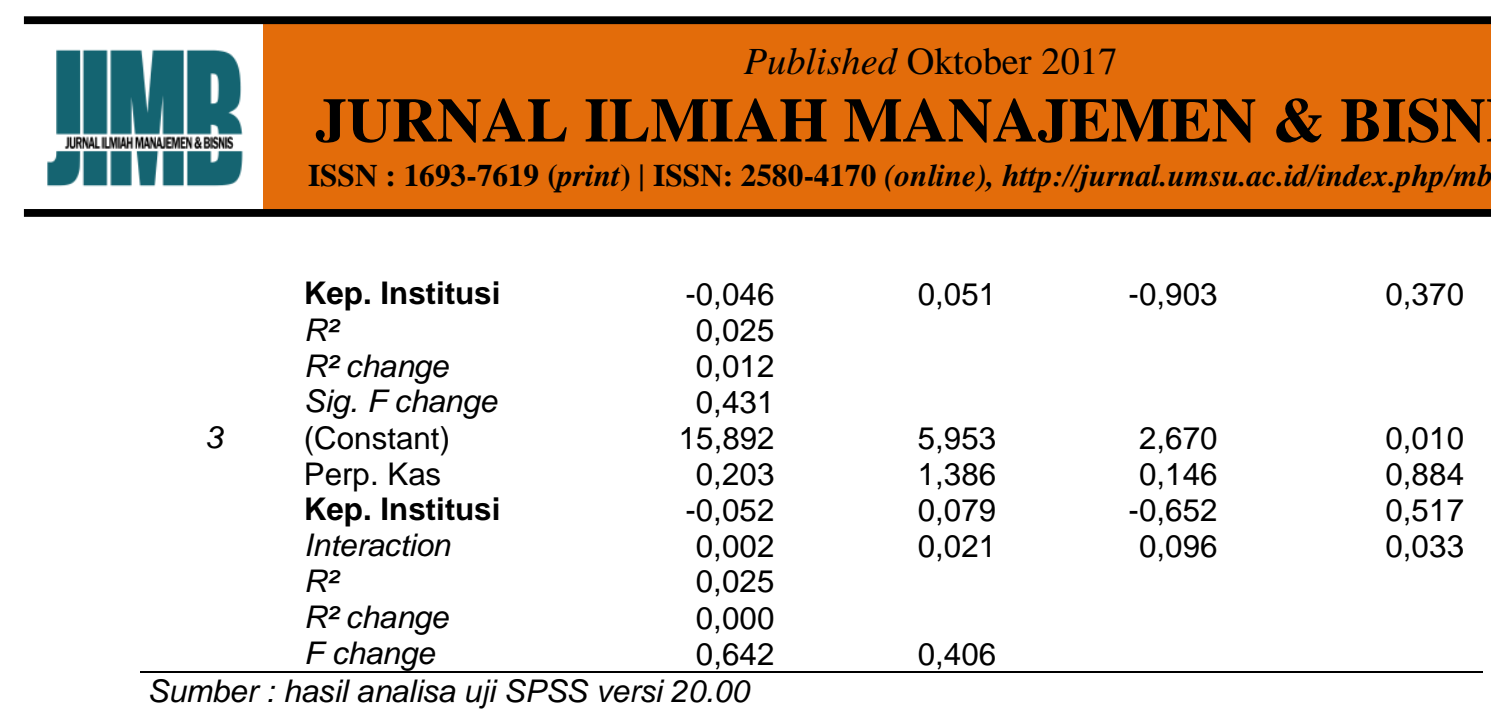

Pada Tabel 2 menunjukkan hasil pengolahan data bahwa $\mathrm{t}_{\text {hitung }}<\mathrm{t}_{\text {tabel }}$ atau $0,944<1.996$ dengan sig $0,349>0,05$ yang artinya $\mathrm{H}_{0}$ diterima, hal ini menunjukan bahwa secara parsial perputaran kas tidak berpengaruh signifikan terhadap Return on Equity. Dengan demikian hipotesis 1 yang menyakatan "Ada pengaruh perputaran kas terhadap Return on Equity pada perusahaan Properti dan Real Estate yang terdaftar di BEI tahun 2010-2014" ditolak. Variabel kepemilikan institusi berperan sebagai moderator terhadap hubungan perputaran kas dengan Return on Equity, dapat dilihat pada tahap pertama dari hasil analisis hierarki regresi pada model 2 , dimana nilai $\mathrm{R}^{2}$ meningkat dari 0,013 menjadi 0,025 atau $\mathrm{R}^{2}$ changes meningkat sebesar 0,012 dan sig. F change menjadi 0,431 . Hubungan parsial dapat dilihat dari nilai Partial regression coefficient sebesar 0,370 dan nilai $\mathrm{t}$ (t.value) $-0,903$ pada tingkat sig. 5\%. Selanjutnya tahap ke 2 untuk melihat ada tidaknya peran kepemilikan institusi sebagai variabel moderating dapat dilihat pada model 3 , yaitu dari hasil interkasi dari hubungan antara perputaran kas terhadap Return on Equity, yang menunjukan nilai $R^{2}$ increases 0,025 tetap dengan nilai 0,025 atau $R^{2}$ change menjadi 0,000 dan sig. $F$ change turun menjadi 0,642. Hubungan parsial dapat dilihat dari Partial Regression coefficient sebesar 0,033 dan nilai $\mathrm{t}(t$ value) sebesar 0,096 dengan sig. 0,05. Artinya hipotesis 2 yang menyatakan "kepemilikan institusi memoderasi pengaruh perputaran kas terhadap Return on Equity" ditolak.

Tabel 3. Hubungan Perputaran Piutang terhadap Return on Equity dimoderasi oleh Kepemilikan Institusi

\begin{tabular}{clrrrr}
\hline $\begin{array}{c}\text { No. } \\
\text { Model }\end{array}$ & Variables & Coefficient & $\begin{array}{c}\text { Standard } \\
\text { Error }\end{array}$ & t-Value & Significant-t \\
\hline 1 & (Constant) & 11,493 & 1,782 & 6,450 & 0,000 \\
& Perp. Piutang & 0,309 & 0,262 & 1,180 & 0,242 \\
& $R^{2}$ & 0,020 & & & \\
& $R^{2}$ change & 0,020 & & & \\
& Sig. F change & 0,242 & & & 0,003 \\
2 & (Constant) & 14,683 & 4,715 & 3,114 & 0,489 \\
& Perp. Piutang & 0,207 & 0,298 & 0,696 & \\
& Kep. Institusi & $-0,039$ & 0,053 & $-0,731$ & 0,467 \\
& $R^{2}$ & 0,028 & & & \\
& $R^{2}$ change & 0,008 & & & 0,011 \\
& Sig. F change & 0,389 & & & 0,930 \\
3 & (Constant) & 16,617 & 6,310 & 2,633 & 0,415 \\
& Perp. Piutang & $-0,056$ & 0,641 & $-0,088$ & \\
& Kep. Institusi & $-0,069$ & 0,084 & $-0,820$ & \\
& Interaction & 0,005 & 0,010 & 0,465 & 0,644 \\
& $R^{2}$ & 0,031 & & &
\end{tabular}




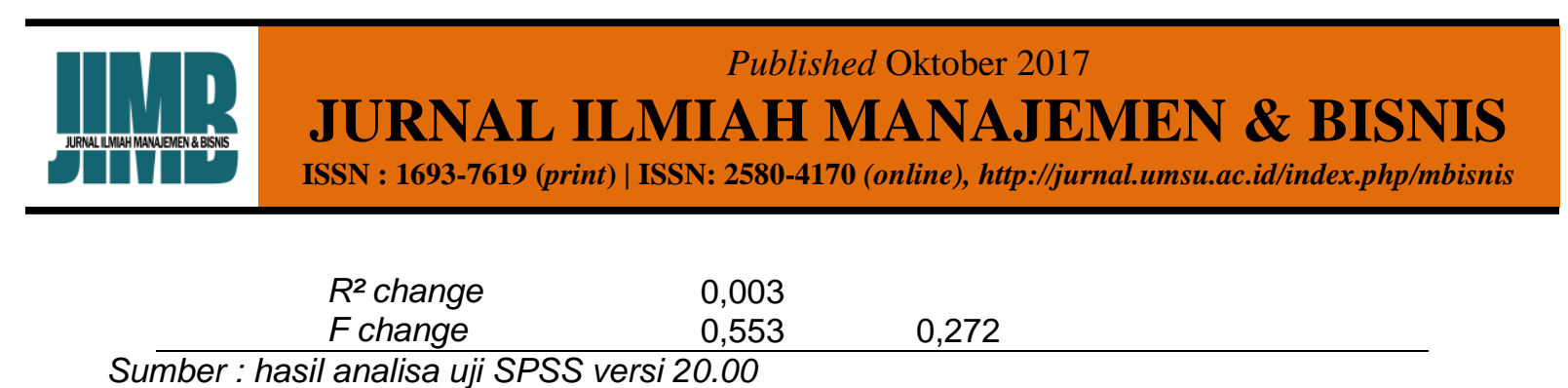

Sumber : hasil analisa uji SPSS versi 20.00

Pada Tabel 3 menunjukkan hasil pengolahan data bahwa besarnya nilai $t_{\text {hitung }}$ $<\mathrm{t}_{\text {tabel }}$ atau 1,180 < 1.996 dengan sig 0,242 $>0,05$ yang artinya $\mathrm{H}_{0}$ diterima, hal ini menunjukan bahwa secara parsial perputaran piutang tidak berpengaruh signifikan terhadap Return on Equity. Hasil interkasi dari hubungan antara perputaran piutang terhadap Return on Equity, yang menunjukan nilai $\mathrm{R}^{2}$ increases 0,028 menjadi 0,031 atau $\mathrm{R}^{2}$ change menjadi 0,003 dan sig. $F$ change turun menjadi 0,553. Hubungan parsial dapat dilihat dari Partial regression coefficient sebesar 0,644 dan nilai $\mathrm{t}(t$ value $)$ sebesar 0,465 dengan tingkat sig. 0,05 . Artinya hipotesis 4 yang menyatakan "kepemilikan institusi memoderasi pengaruh perputaran piutang terhadap Return on Equity" ditolak.

Tabel 4. Hubungan Perputaran Aktiva Tetap terhadap Return on Equity dimoderasi oleh Kepemilikan Institusi

\begin{tabular}{|c|c|c|c|c|c|}
\hline $\begin{array}{c}\text { No. } \\
\text { Model }\end{array}$ & Variables & Coefficient & $\begin{array}{c}\text { Standard } \\
\text { Error }\end{array}$ & t-Value & Significant-t \\
\hline \multirow[t]{5}{*}{1} & (Constant) & 10,713 & 1,357 & 7,893 & 0,000 \\
\hline & Perp. Ak. Tetap & 0,141 & 0,050 & 2,851 & 0,006 \\
\hline & $R^{2}$ & 0,107 & & & \\
\hline & $R^{2}$ change & 0,107 & & & \\
\hline & Sig. F change & 0,006 & & & \\
\hline \multirow[t]{6}{*}{2} & (Constant) & 15,464 & 3,220 & 4,802 & 0,000 \\
\hline & Perp. Ak. Tetap & 0,151 & 0,049 & 3,056 & 0,003 \\
\hline & Kep. Institusi & $-0,072$ & 0,044 & $-1,623$ & 0,109 \\
\hline & $R^{2}$ & 0,141 & & & \\
\hline & $R^{2}$ change & 0,034 & & & \\
\hline & Sig. F change & 0,006 & & & \\
\hline \multirow[t]{7}{*}{3} & (Constant) & 9,336 & 3,353 & 2,784 & 0,007 \\
\hline & Perp. Ak. Tetap & 1,041 & 0,239 & 4,359 & 0,000 \\
\hline & Kep. Institusi & 0,022 & 0,047 & 0,470 & 0,640 \\
\hline & Interaction & $-0,013$ & 0,003 & $-3,796$ & 0,000 \\
\hline & $R^{2}$ & 0,295 & & & \\
\hline & $R^{2}$ change & 0,154 & & & \\
\hline & F change & 0,000 & 1,591 & & \\
\hline
\end{tabular}

Pada Tabel 4 menunjukkan hasil pengolahan data bahwa Dari hasil pengolahan data diperoleh nilai $\mathrm{t}_{\text {hitung }}<\mathrm{t}_{\text {tabel }}$ atau 2,851 $>1.996$ dengan sig $0,006<0,05$ yang artinya $\mathrm{H}_{0}$ ditolak, hal ini menunjukan bahwa secara parsial perputaran aktiva tetap berpengaruh signifikan terhadap Return on Equity. hasil interkasi dari hubungan antara perputaran aktiva tetap terhadap Return on Equity, yang menunjukan nilai $\mathrm{R}^{2}$ increases 0,141 menjadi 0,295 atau $R^{2}$ change menjadi
0,154 dan sig. F change naik menjadi 0,000 . Hubungan parsial dapat dilihat dari Partial regression coefficient sebesar 0,000 dan nilai $t$ (t.Value) sebesar -3,796 dengan tingkat sig. 0,05. Artinya hipotesis 6 yang menyatakan "kepemilikan institusi memoderasi pengaruh Perputaran Aktiva Tetap terhadap Return on Equity" diterima. 


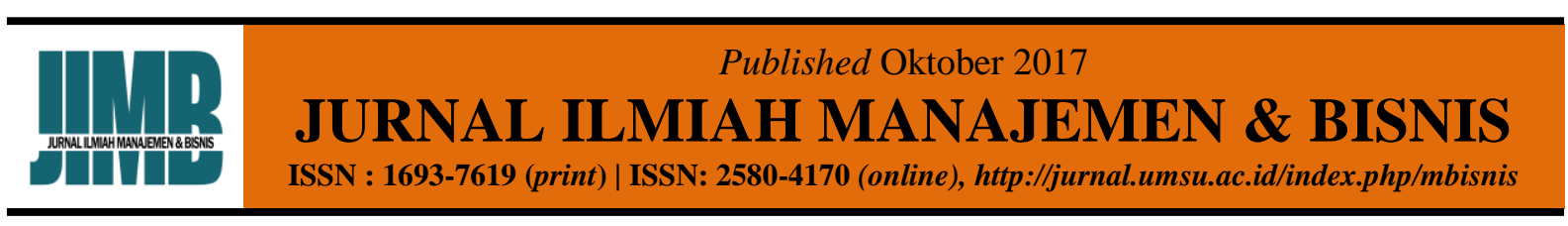

Tabel 5. Uji F

\begin{tabular}{lrrrrr}
\multicolumn{6}{c}{ ANOVA $^{\mathrm{a}}$} \\
\hline Model & $\begin{array}{c}\text { Sum of } \\
\text { Squares }\end{array}$ & df & Mean Square & F & Sig. \\
\hline Regression & 890,874 & 3 & & & \\
1 Residual & 5064,531 & 66 & 76,958 & 3,870 &, $013^{\mathrm{b}}$ \\
Total & 5955,405 & 69 & & & \\
Detal & & & & &
\end{tabular}

a. Dependent Variable: ROE

b. Predictors: (Constant), Perputaran Aktiva Tetap, Perputaran

Piutang, Perputaran Kas

Sumber : hasil uji SPSS versi 20.00

Pada Tabel 5 diperoleh hasil perhitungan bahwa $\mathrm{F}_{\text {hitung }} \quad=3,870 \quad \mathrm{~F}_{\text {tabel }}$ $=\mathrm{n}-\mathrm{k}-1=70-3-1=66$ Berdasarkan hasil uji $F_{\text {hitung }}$ pada tabel diatas, diperoleh nilai $F_{\text {hitung }}$ sebesar 3,870 dengan nilai signifikan 0,013, sementara nilai $\mathrm{F}_{\text {tabel }}$ berdasarkan $\mathrm{dk}=\mathrm{n}-\mathrm{k}-1$ $=70-3-1=66$ dengan tingkat signifikan 5\% adalah 2,74. Berdasarkan hasil pengujian pada gambar diatas maka dapat dinyatakan bahwa $F_{\text {hitung }}$ jatuh pada daerah penolakan $\mathrm{H}_{0}$ atau dengan kata lain 3,870 > 2,74 atau $3,870<-2,74$. Hal ini menunjukan bahwa Perputaran Kas, Perputaran Piutang dan Perputaran Aktiva Tetap secara bersamasama berpengaruh signifikan terhadap Return on Equity.

Tabel 6. Hubungan Perputaran Kas, Perputaran Piutang dan Perputaran

Aktiva Tetap secara simultan terhadap Return on Equity dimoderasi oleh Kepemilikan Institusi

\begin{tabular}{|c|c|c|c|c|c|}
\hline $\begin{array}{c}\text { No. } \\
\text { Model }\end{array}$ & Variables & Coefficient & $\begin{array}{c}\text { Standard } \\
\text { Error }\end{array}$ & t-Value & Significant-t \\
\hline \multirow[t]{7}{*}{1} & (Constant) & 7,852 & 2,071 & 3,792 & 0,000 \\
\hline & Perp. Kas & 0,395 & 0,836 & 0,473 & 0,638 \\
\hline & Perp.Piutang & 0,304 & 0,386 & 0,788 & 0,434 \\
\hline & Perp. Ak. Tetap & 0,159 & 0,050 & 3,170 & 0,002 \\
\hline & $R^{2}$ & 0,150 & & & \\
\hline & $R^{2}$ change & 0,150 & & & \\
\hline & Sig. F change & 0,013 & & & \\
\hline \multirow[t]{8}{*}{2} & (Constant) & 11,520 & 4,591 & 2,509 & 0,015 \\
\hline & Perp. Kas & 0,368 & 0,838 & 0,440 & 0,662 \\
\hline & Perp. Piutang & 0,197 & 0,404 & 0,487 & 0,628 \\
\hline & Perp. Ak. Tetap & 0,161 & 0,050 & 3,197 & 0,002 \\
\hline & Kep. Institusi & $-0,045$ & 0,050 & $-0,896$ & 0,374 \\
\hline & $R^{2}$ & 0,160 & & & \\
\hline & $R^{2}$ change & 0,010 & & & \\
\hline & Sig. F change & 0,021 & & & \\
\hline \multirow[t]{9}{*}{3} & (Constant) & $-3,993$ & 5,761 & 0,693 & 0,491 \\
\hline & Perp. Kas & 1,368 & 0,801 & 1,707 & 0,093 \\
\hline & Perp. Piutang & 0,948 & 0,414 & 2,289 & 0,025 \\
\hline & Perp. Ak. Tetap & 1,026 & 0,227 & 4,523 & 0,000 \\
\hline & Kep. Institusi & 0,169 & 0,071 & 2,372 & 0,021 \\
\hline & Interaction & $-0,012$ & 0,003 & $-3,893$ & 0,000 \\
\hline & $R^{2}$ & 0,321 & & & \\
\hline & $R^{2}$ change & 0,161 & & & \\
\hline & F change & 0,000 & & & \\
\hline
\end{tabular}


Pada Tabel 6 menunjukkan dari hasil uji interaksi dari hubungan antara perputaran kas, perputaran piutang dan perputaran aktiva tetap terhadap Return on Equity, yang menunjukan R2 meningkat dari 0,160 menjadi 0,321 atau R2 Change meningkat sebesar 0,161 dan sig. F.Change juga meningkat dari 0,021 menjadi 0,000. Hubungan parsial dapat dilihat dari Partial regression coefficient sebesar 0,000 dan nilai $\mathrm{t}$ (t.Value) sebesar $-3,893$ dengan tingkat sig. 0,05. Artinya hipotesis 8 yang menyatakan "Kepemilikan Institusi memoderasi pengaruh Perputaran Kas, Perputaran Piutang dan Perputaran Aktiva Tetap secara simultan terhadap Return on Equity" diterima.

Tabel 7. Uji T

Coefficients $^{a}$

\begin{tabular}{|c|c|c|c|c|c|c|c|c|}
\hline \multirow[t]{2}{*}{ Model } & \multicolumn{2}{|c|}{$\begin{array}{c}\text { Unstandardiz } \\
\text { ed } \\
\text { Coefficients }\end{array}$} & \multirow{2}{*}{$\begin{array}{c}\text { Standardize } \\
d \\
\text { Coefficients } \\
\text { Beta }\end{array}$} & \multirow[t]{2}{*}{$t$} & \multirow[t]{2}{*}{ Sig. } & \multicolumn{3}{|c|}{ Correlations } \\
\hline & B & $\begin{array}{l}\text { Std. } \\
\text { Error }\end{array}$ & & & & $\begin{array}{l}\text { Zero- } \\
\text { order }\end{array}$ & $\begin{array}{c}\text { Partia } \\
\text { I }\end{array}$ & Part \\
\hline (Constant) & $\begin{array}{r}16,96 \\
8\end{array}$ & 3,372 & & 5,032 & ,000 & & & \\
\hline $\begin{array}{l}\text { Kepemilika } \\
\text { n Institusi }\end{array}$ &,- 056 & ,047, &,- 144 & $-1,202$ & ,234 &,- 144 &,- 144 &,- 144 \\
\hline
\end{tabular}

a. Dependent Variable: ROE

Sumber : hasil uji SPSS versi 20.00

Pada Tabel 7 menunjukkan hasil pengolahan data bahwa nilai $t_{\text {hitung }}$ sebesar 1,202 dan sig. 0,234. Hal ini menunjukan bahwa secara parsial Kepemilikan Institusi tidak berpengaruh signifikan terhadap Return on Equity. artinya hipotesis ke 9 yang menyatakan "Kepemilikan Institusi berpengaruh terhadap Return on Equity" ditolak.

\section{PEMBAHASAN}

\section{Pengaruh Perputaran Kas terhadap Return on Equity dimoderasi oleh Kepemilikan Institusi}

Hasil uji hipotesis secara parsial menunjukan bahwa nilai $t_{\text {hitung }}$ untuk variabel Perputaran Kas adalah 0,944 dan $t_{\text {tabel }}$ dengan $\alpha=0,05$ diketahui sebesar 1.996. Dengan demikian $-t_{\text {tabel }} \leq t_{\text {hitung }} \leq t_{\text {tabel }}$ $(-1.996 \leq 0,944 \leq 1.996)$ dan bila dilihat dari gambar hipotesis dua arah bahwa $t_{\text {hitung }}$ jatuh pada daerah penerimaan $\mathrm{H}_{0}$, artinya $\mathrm{H}_{0}$ diterima dan $\mathrm{H}_{\mathrm{a}}$ ditolak. Berdasarkan hasil tersebut bahwa secara parsial tidak ada pengaruh signifikan Perputaran Kas terhadap Return on Equity pada perusahaan Properti dan Real Estate yang terdaftar di Bursa Efek Indonesia tahun 2010-2014.

Berpengaruh positif tidak signifikan Perputaran Kas terhadap Return on Equity. Artinya apabila modal kerja meningkat dan dapat digunakan sebagai modal untuk membiayai kegiatan perusahaan dalam menghasilkan pandapatan atau dengan kata lain perusahaan mampu membiayai kebutuhan perusahaan yang sesegera mungkin dibayar (Kasmir, 2012). Artinya perputaran kas yang meningkat akan berdampak baik bagi kegiatan perusahaan, akan tetapi tidak perpengaruh langsung terhadap meningkatnya Return On Equity perusahaan. Hal ini berarti semakin tinggi Perputaran Kas tidak mempengaruhi tingginya Return on Equity perusahaan. Hasil penelitian ini sejalan dengan penelitian yang dilakukan oleh Ahmad Ishak (2008) yang menyatakan bahwa Perputaran Kas tidak berpengaruh signifikan terhadap Return on Equity. 
Selanjutnya untuk hipotesis ke-2 yang menggunakan uji Analisis Regresi Hierarki (HRA) untuk mengetahui ada tidaknya efek moderating variabel dari kepemilikan institusi terhadap hubungan Perputaran Kas dengan Return on Equity dapat dilihat dengan hasil interaksi dimana nilai $\mathrm{R}^{2}$ tetap dengan nilai 0,025 , artinya tidak mengalami peningkatan $\mathrm{R}^{2}$ change, dan signifikan $\mathrm{F}$ change 0,431 turun menjadi 0,642 pada tingkat signifikan $5 \%$. Hubungan parsial dapat dilihat dari Partial regression coefficient sebesar 0,033 dan nilai t (t.value) sebesar 0,096 dengan tingkat sig 5\%. Hal ini menunjukan bahwa Kepemilikan Institusi tidak memberikan efek pada hubungan Perputaran Kas terhadap Return On Equity. Dikarenakan kepemilikan institusi sebagai kepemilikan saham pihak eksternal, meningkatnya kepemilikan institusi tidak mempengaruhi pada hubungan perputaran kas terhadap Return on Equity sehingga meningkatnya saham pada perusahaan belum tentu meningkatkan Return on Equity perusahaan yang dihasilkan oleh Perputaran Kas.

Berdasarkan hasil penelitian yang dilakukan peneniliti, pendapat maupun penelitian terdahulu yang telah dikemukakan diatas maka penulis menyimpulkan bahwa antara Perputaran Kas terhadap Return on Equity adalah memiliki hubungan positif tetapi tidak berpengaruh signifikan. Serta Kepemilikan Institusi tidak memoderasi hubungan Perputaran Kas terhadap Return on Equity. Penelitian ini sejalan dengan penelitian Yuliati dan Sunarto, (2014); Jufrizen, (2014) yang yang mengatakan bahwa terdapat pengaruh perputaran kas terhadap profitabilitas. Suatu perusahaan dapat diindikasikan berhasil apabila perputaran kas yang terjadi selama periode keuangan tertentu mengalami kenaikan. Perputaran kas yang terjadi selama periode tertentu dapat dijadikan sebagai acuan para investor dalam menambah investasi bagi perusahaan dalam pendanaan operasional dimasa yang akan datang. Perputaran kas merupakan perbandingan antara penjualan dengan jumlah kas rata-rata. Berbeda hal nya dengan Penelitian yang dilakukan oleh Suminar, (2015) bahwa perputaran kas berpengaruh negatif tidak signifikan terhadap ROE.

\section{Pengaruh Perputaran Piutang terhadap Return on Equity dimoderasi oleh Kepemilikan Institusi}

Hasil uji hipotesis secara parsial menyatakan bahwa $-\mathrm{t}_{\text {tabel }} \leq \mathrm{t}_{\text {hitung }} \leq \mathrm{t}_{\text {tabel }}$ dengan nilai yakni $-1.996 \leq 1,180 \leq 1.996$. Dan bila dilihat dari gambar hipotesis dua arah bahwa $t_{\text {hitung jatuh pada daerah }}$ penerimaan $\mathrm{H}_{0}$, artinya $\mathrm{H}_{0}$ diterima dan $\mathrm{H}_{\mathrm{a}}$ ditolak. Berdasarkan hasil tersebut bahwa secara parsial tidak ada pengaruh signifikan Perputaran Piutang terhadap Return on Equity pada perusahaan Properti dan Real Estate yang terdaftar di Bursa Efek Indonesia tahun 2010-2014. Berpengaruh positif tidak signifikan Perputaran Piutang terhadap Return on Equity sesuai dengan nilai regresi sebesar 0,304 membuktikan bahwa Perputaran Piutang memiliki hubungan yang postitif terhadap Return on Equity. Artinya perputaran piutang yang semakin tinggi adalah semakin baik, karena modal kerja yang ditanamkan dalam bentuk piutang akan semakin rendah (Jumingan, 2009). Meningkatnya perputaran piutang tidak secara langsung menyebabkan Return on Equity perusahaan juga meningkat hal ini dikarenakan piutang merupakan strategi atau kebijakan perusahaan untuk menjaga modal kerja atau dana yang ditanam dalam piutang terus berputar. Hal ini berarti semakin tinggi perputaran piutang tidak berpengaruh langsung terhadap tingginya Return on Equity perusahaan. Hasil peneilitian ini sejalan dengan penelitian yang dilakukan oleh Hening (2013) yang menyatakan Perputaran Piutang berpengaruh tidak signifikan terhadap Profitabilitas. Namun 
lain halnya dengan penelitian yang dilakukan oleh Ahmad Ishak (2008) yang menyatakan bahwa Perputaran Piutang berpengaruh signifikan terhadap Return on Equity.

Selanjutnya untuk hipotesis ke-4 yang menggunakan uji Analisis Regresi Hierarki (HRA) untuk mengetahui ada tidaknya efek moderating variabel dari kepemilikan institusi terhadap hubungan Perputaran Piutang dengan Return on Equity dapat dilihat dengan hasil interaksi dimana nilai $\mathrm{R}^{2} \quad 0,028$ menjadi 0,031 , artinya $\mathrm{R}^{2}$ change meningkat 0,003 , dan signifikan $\mathrm{F}$ change 0,389 turun menjadi 0,553 pada tingkat signifikan 5\%. Hubungan parsial dapat dilihat dari Partial regression coefficient sebesar 0,644 dan nilai t (t.value) sebesar 0,465 dengan tingkat sig 5\%. Hal ini menunjukan bahwa dengan adanya kepemilikan institusi tidak memberikan efek yang tinggi pada pengaruh Perputaran Piutang terhadap Return on Equity. dikarenakan Kepemilikan Isntitusi yang dimiliki perusahaan tidak cukup untuk meningkatkan Return on Equity yang dihasilkan melalui Perputaran Piutang.

Berdasarkan hasil penelitian yang dilakukan peneniliti, pendapat maupun penelitian terdahulu yang telah dikemukakan diatas maka penulis menyimpulkan bahwa Perputaran Piutang berpengaruh tidak signifikan terhadap Return on Equity. Serta Kepemilikan Intitusi tidak memoderasi pengaruh perputaran piutang terhadap Return on Equity.

\section{Pengaruh Perputaran Aktiva Tetap terhadap Return on Equity dimoderasi oleh Kepemilikan Institusi}

Hasil uji hipotesis secara parsial menyatakan bahwa $t_{\text {hitung }}>1.995$ atau $-\mathrm{t}_{\text {hitung }}$ $<-1.995$ dengan nilai yakni $3.170>1.995$ atau $-3.170<-1.995$. Dan bila dilihat dari gambar hipotesis dua arah bahwa $t_{\text {hitung }}$ jatuh pada daerah penolakan $\mathrm{H}_{0}$, artinya $\mathrm{H}_{0}$ ditolak dan $\mathrm{H}_{\mathrm{a}}$ diterima. Berdasarkan hasil tersebut bahwa secara parsial ada pengaruh signifikan Perputaran Aktiva Tetap terhadap Return on Equity pada perusahaan Properti dan Real Estate yang terdaftar di Bursa Efek Indonesia tahun 2010-2014.Berpengaruh positif signifikan Perputaran Aktiva Tetap terhadap Return on Equity sesuai dengan nilai regresi sebesar 0,159 membuktikan bahwa Perputaran Aktiva Tetap memiliki hubungan yang postitif terhadap Return on Equity. Artinya meningkatnya perputaran aktiva tetap akan sangat baik bagi perusahaan karena aktiva tetap adalah aktiva yang sesungguhnya menghasilkan pendapatan bagi perusahaan oleh karena itu aktiva-aktiva tetap inilah yang memberikan dasar bagi "earning power". (Syamsuddin, 2009). Dengan demikian meningkatnya perputaran aktiva tetap menunjukan kemampuan perusahaan menggunakan aktiva tetapnya untuk menunjang penjualan yang akan meningkatkan laba atau keuntungan bagi perusahaan. Meningkatnya keuntungan atau laba yang dihasilkan perusahaan dapat memberikan keuntungan bagi para pemegang saham (pemegang saham biasa). Untuk itu kenaikan perputaran aktiva tetap dapat secara langsung meningkatkan Return on Equity perusahaan, hal ini disebabkan karena salah satu faktor yang mempengaruhi Return on Equity adalah Total Asset Turnover (efisiensi penggunaan aktiva) adalah rasio pengukuran tingkat efisiensi penggunaan total aktiva dalam menghasilkan penjualan. Hal ini berarti semkin tinggi Perputaran Aktiva Tetap mempengaruhi Return on Equity. Hasil penelitian ini tidak sejalan dengan penelitian Syahputri, (2015) yang menyatakan bahwa Perputaran Aktiva Tetap berpengaruh tidak signifikan terhadap Return on Equity.

Selanjutnya untuk hipotesis ke-6 yang menggunakan uji Analisis Regresi Hierarki (HRA) untuk mengetahui ada tidaknya efek moderating variabel dari kepemilikan institusi terhadap hubungan 
Perputaran Aktiva Tetap dengan Return on Equity dapat dilihat dengan hasil interaksi dimana nilai $\mathrm{R}^{2} \quad 0,141$ menjadi 0,295 , artinya $\mathrm{R}^{2}$ change meningkat 0,154 , dan signifikan $\mathrm{F}$ change 0,006 meningkat menjadi 0,000 pada tingkat signifikan $5 \%$. Hubungan parsial dapat dilihat dari Partial regression coefficient sebesar 0,000 dan nilai $\mathrm{t}$ (t.value) sebesar -3,796 dengan tingkat sig 5\%. Artinya pada kondisi ini Kepemilikan Institusi memberikan efek pada pengaruh Perputaran Aktiva Tetap terhadap Return on Equity, dapat dilihat dengan adanya Kepemilikan Institusi meningkatkan pengaruh Perputaran Aktiva Tetap terhdap Return On Equity, sehingga meningkatnya saham atau kepercayaan pihak eksternal kepada perusahaan dapat meningkatkan Return On Equity melalui meningkatnya Perputaran Aktiva Tetap yang dimiliki perusahaan. Kepemilikan institusi dapat menjadi motivasi bagi perusahaan agar lebih meningkatkan kinerja untuk menghasilkan keuntungan yang lebih banyak.

Berdasarkan hasil penelitian yang dilakukan penulis serta teori, pendapat, maupun penelitian terdahulu, maka penulis menyimpulkan bahwa antara Perputaran Aktiva Tetap berpengaruh signifikan terhadap Return on Equity. Serta Kepemilikan Institusi memoderasi pengaruh perputaran aktiva tetap terhadap Return on Equity

\section{Pengaruh Perputaran Kas, Perputaran Piutang dan Perputaran Aktiva Tetap secara bersama-sama terhadap Return on Equity dimoderasi oleh Kepemilikan Institusi.}

Berdasarkan uji $F$ yang menguji secara simultan yaitu apakah variabel Perputaran Kas, Perputaran Piutang dan Perputaran Aktiva Tetap secara simultan berpengaruh signifikan terhadap variabel terikat yaitu Return on Equity. Diperoleh nilai $F_{\text {hitung }}$ sebesar 3,870 dengan nilai signifikan 0,013. Hal ini menunjukan bahwa nilai $F_{\text {hitung }}>F_{\text {tabel }}$ atau 3,870 $>2,74$ maka $\mathrm{F}_{\text {hitung }}$ berada pada daerah penolakan $\mathrm{H}_{0}$ dan terima $\mathrm{H}_{\mathrm{a}}$. Hal ini berarti ada pengaruh signifikan secara simultan antara Perputaran Kas, Perputaran Piutang dan Peprutaran Aktiva Tetap terhadap Return on Equity pada perusahaan Properti dan Real Estate yang terdaftar di Bursa Efek Indonesia tahun 2010-2014. Selanjutnya untuk hipotesis ke-8 yang menggunakan uji Analisis Regresi Hierarki (HRA) untuk mengetahui ada tidaknya efek moderating variabel dari kepemilikan institusi terhadap hubungan Perputaran Kas, Perputaran Piutang dan Perputaran Aktiva Tetap secara simultan dengan Return on Equity dapat dilihat dengan hasil interaksi dimana nilai $\mathrm{R}^{2} 0,160$ menjadi 0,321 , artinya $R^{2}$ change meningkat 0,161 , dan signifikan $F$ change 0,021 meningkat menjadi 0,000 pada tingkat signifikan $5 \%$. Hubungan parsial dapat dilihat dari Partial regression coefficient sebesar 0,000 dan nilai $t$ (t.value) sebesar 3,893 dengan tingkat sig 5\%. Artinya pada kondisi ini Kepemilikan Institusi memberikan efek pada perputaran kas, perputaran piutang dan pengaruh perputaran aktiva tetap terhadap Return on Equity, dapat dilihat dengan adanya Kepemilikan Institusi meningkatkan pengaruh Perputaran Kas, Perputaran Piutang Dan Perputaran Aktiva Tetap terhadap Return On Equity, sehingga meningkatnya saham atau kepercayaan pihak eksternal kepada perusahaan dapat meningkatkan Return On Equity melalui meningkatnya Perputaran Kas, Perputaran Piutang dan Perputaran Aktiva Tetap yang dimiliki perusahaan. Kepemilikan institusi mempunyai peran pada perusahaan, semakin tinggi kepemilikan institusi memberikan pengaruh yang besar terhadap perusahaan.

Begitu pula dengan Kepemilikan Institusi semakin besar kepemilikan institusi keuangan maka akan semakin besar kekuatan suara dan dorongan dari institusi 
keuangan tersebut untuk mengawasi manajemen dan akibatnya akan memberikan dorongan yang lebih besar untuk mengoptimalkan nilai perusahaan sehingga kinerja perusahaan akan meningkat. Kinerja yang meningkat tersebut akan menguntungkan bagi pemegang saham karena dengan kata lain pemegang saham akan mendapatkan banyak keuntungan berupa dividen (Patricia, 2014, hal. 16). Berdasarkan hasil penelitian yang dilakukan oleh peneliti, maka peneliti dapat menyimpulkan bahwa secara simultan Perputaran Kas, Perputaran Piutang dan Perputaran Aktiva Tetap berpengaruh signifikan terhadap Return on Equity. Serta Kepemilikan Institusi memoderasi pengaruh Perputaran Kas, Perputaran Piutang dan Perputaran Aktiva Tetap secara simultan terhadap Return on Equity.

\section{Pengaruh Kepemilikan Institusi terhadap Return on Equity.}

Hasil uji hipotesisi secara parsial menyatakan bahwa Kepemilikan Institusi memiliki nilai signifikan sebesar 0,234 > 0,05 dan nilai t (t.value) sebesar -1,202. Berdasarkan hasil tersebut bahwa secara parsial Kepemilikan Institusi berpengaruh tidak signifikan terhadap Return on Equity. Artinya kepemilikan institusi tidak mempengaruhi meningkatnya Return on Equity dikarenakan kepemilikan institusi merupakan kepemilikan saham oleh pihak eksternal, tidak berhubungan secara langsung dengan kegiatan perusahaan yang dapat meningkatkan laba, dan kepemilikan institusi bertindak sebagai pengawas untuk menjaga kemakmuran para pemegang saham. Hal ini membuktikan bahwa kepemilikan institusi tidak berpengaruh terhadap meningkatnya Return on Equity perusahaan Properti dan Real Estate yang terdaftar di BEI tahun 2010-2014. Dari hasil penelitian terdahulu yang dilakukan oleh Wico (2015) yang juga menyatakan bahwa Kepemilikan Institusi tidak berpengaruh signifikan terhadap Return on Equity. Berdasarkan hasil penelitian yang dilakukan penulis serta teori, pendapat, maupun penelitian terdahulu, maka penulis menyimpulkan bahwa antara Kepemilikan Institusi tidak berpengaruh signifikan terhadap Return on Equity.

\section{SIMPULAN}

Berdasarkan hasil penelitian dan pembahasan yang telah dikemukakan sebelumnya maka dapat disimpulkan bahwa ada pengaruh yang tidak signifikan secara parsial antara Perputaran Kas terhadap Return on Equity. Kepemilikan Institusi tidak memoderasi pengaruh Perputaran Kas terhadap Return on Equity. Ada pengaruh yang tidak signifikan secara parsial antara Perputaran Piutang terhadap Return on Equity. Kepemilikan Institusi tidak memoderasi pengaruh Perputaran Piutang terhadap Return on Equity. Ada pengaruh yang signifikan secara parsial antara Perputaran Aktiva Tetap terhadap Return on Equity. Kepemilikan Institusi memoderasi pengaruh Perputaran Aktiva Tetap terhadap Return on Equity. Ada pengaruh signifikan secara simultan antara Perputaran Kas, Perputaran Piutang dan Perputaran Aktiva Tetap terhadap Return on Equity. Kepemilikan Institusi memoderasi pengaruh Perputaran Kas, Perputaran Piutang dan Perputaran Aktiva Tetap secara bersamasama terhadap Return on Equity. Ada pengaruh tidak signifikan secara parsial antara Kepemilikan Institusi terhadap Return on Equity. Untuk para manajer perusahaan agar lebih memperhatikan dan menjaga tingkat modal kerja perusahaan agar lebih bisa mengefisiensikan untuk bisa memaksimalkan laba perusahaan dan dalam penelitian ini Aktiva Tetap memiliki pengaruh yang signifikan sehingga disarankan perusahaan untuk lebih menjaga dan mengendalikan aset-aset atau kekayaan yang dimiliki perusahaan untuk menunjang keberhasilan atau tujuan yang ingin dicapai. 
Diharapkan perusahaan mengoptimalkan tingkat ROE sehingga modal yang dimiliki perusahaan dapat menghasilkan laba bersih yang menguntungkan perusahaan dan para pemegang saham. Bagi peneliti selanjutnya, disarankan agar sebaiknya menggunakan variabel yang jarang diteliti oleh peneliti lain dan juga menggunakan periode penelitian yang lebih panjang sehingga diharapkan memperoleh hasil yang lebih akurat agar dapat diketahui lebih jelas pengaruh Profitabilitas suatu perusahaan dalam memenuhi kewajiban perusahaan dalam mensejahterahkan karyawan, investor dan semua pihak yang berkaitan dengan perusahaan.

\section{REFERENSI}

Brigham, E, ., dan Houston, J. F. (2010). Dasar-Dasar Manajemen Keuangan. Edisi Sebelas Buku Satu. Jakarta: Salemba Empat

Darsono, Ari Purwanti. (2010). Penganggaran Perusahaan. Edisi Dua. Jakarta : Mitra Wacana Media.

Fajri, A. (2013). Pengaruh Perputaran Modal Kerja Terhadap Profitabilitas Pada Perusahaan Makanan Dan Minuman Yang Terdaftar Di Bursa Efek Indonesia. Skripsi. Universitas Sumatera Utara.

Hani Syafrida. (2014). Teknik Analisa Laporan Keuangan. Medan : UMSU Press

Hery. (2012). Akuntansi Keuangan Menengah.Edisi Satu Cetakan dua. Jakarta : Bumi Aksara.

Hening, W. O. (2013). Pengaruh Perputaran Kas, Piutang dan Persediaan terhadap Profitabilitas Perusahaan Pakan Ternak. Jurnal Sekolah Tinggi Ilmu Ekonomi Indonesia (STIESIA) Surabaya.

Ishak Setyawan Achmad. (2009). Pengaruh Perputaran Modal Kerja (Perputaran Kas, Perputaran Piutang, Dan perputaran persediaan) terhadap
Profitabilitas (Studi pada Perusahaan Manufaktur yang Listing di BEI periode 2005-2007). Jurnal Universitas Negeri Malang.

Wico, J. T. (2015). Pengaruh Current Ratio, Debt To Equity Ratio, Total Asset Turnover dan Inventory Turnover terhadap Return On Equity dengan Kepemilikan Institusional sebagai Variabel Moderating pada Perusahaan Perdagangan Eceran yang terdaftar di Bursa Efek Indonesia. Skripsi. Universitas Sumatera Utara.

Jufrizen. (2014). Pengaruh Perputaran Kas Dan Perputaran Persediaan Terhadap Profitabilitas Pada Perusahaan Plastik Dan Kemasan Yang Terdaftar Di Bei Jufrizen. Jurnal Ekonomikawan, 14(2), 131-138.

Jumingan. (2009). Analisis Laporan Keunagan. Jakarta : Bumi AksaraJakarta.

Kasmir. (2012). Analisis Laporan Keuangan. Cetakan Keempat. Jakarta: Rajawali Pers.

Martani, D. (2012). Akuntansi Keuangan Menengah. Buku Satu. Jakarta: Salemba Empat.

Marselina , W, Pranata P. Midiastuty, dan Suranta, E. (2013). Dividend Policy and Foreign Ownership. Simposium Nasional Akuntansi XVI, 3401-3423.

Munawir S. (2010). Analisis Laporan Keuangan. Cetakan 14. Edisi Keempat.Yogyakarta : Liberty

Riyanto, B. (2010). Dasar-Dasar Pembelanjaan Perusahaan. Edisi Empat. Yogyakarta: BPFE

Ross, Westerfield, Jordan. (2009). Pengantar Keuangan Perusahaan. Edisi delapan Buku satu. Jakarta : Salemba Empat.

Sudana Made. (2011). Manajemen Keuangan Perusahaan Teori dan Praktik. Jakarta : Erlangga.

Sugiyono. (2012). Metode Penelitian Bisnis. Bandung : Alfabeta 
Syahrial Dermawan. (2013). Analisa Laporan Keuangan-Cara Mudah dan praktis Memahami Laporan Keuangan. Edisi Dua. Jakarta : Mitra Wacana Media.

Syahputri Elpika. (2015). Pengaruh Inventory Turnover Dan Fixed Asset Turnover Terhadap Return on Equity (ROE) Pada perusahaan farmasi Yang terdaftar di BEI tahun 2007-201. Skripsi Universitas Muhammadiyah Sumatera Utara. Tidak Dipublikasikan.

Prawironegoro, D., dan Purwanti, A. (2008). Akuntansi manajemen. Edisi ke-2. Jakarta: Mitra Wacana Media.

Shien, et.al, 2006 Financial Accounting Theory 3th editon. Pearson Prentice Hall .

Syamsuddin, L. (2009). Manajemen Keuangan Perusahaan. Edisi baru. Jakarta : Rajawali Pers.

Suminar, M. T. (2015) Pengaruh Perputaran Persediaan, Perputaran Piutang Dan Perputaran Kas Terhadap Profitabilitas Pada Perusahaan Sektor Industri Barang Konsumsi Yang Terdaftar Di Bei Periode 2008-2013. Journal of Accounting: Jurnal Ilmiah Mahasiswa S1 Akuntansi Universitas Pandanaran, 1(1), 1-19.

Widarjo, W. (2010). Pengaruh Ownership Retention, Investasi Dari Proceeds Dan Reputasi Auditor Terhadap Nilai Perusahaan Dengan Kepemilikan Manajerial Dan Institusional Sebagai Variabel Pemoderasi. Tesis. Fakultas Ekonomi Universitas Sebelas Maret Surakarta.

Yuliyati., dan Sunarto. (2014). Pengaruh Perputaran Modal Kerja, Perputaran Kas, Dan Struktur Modal Terhadap Profitabilitas Perusahaan Penyedia Spare Part Otomotif Periode 20072011. Jurnal Akuntansi. 2(1), 56-65. 